\title{
AN “ACID” PHOSPHATASE OCCURRING IN THE SERUM OF PATIENTS WITH METASTASIZING CARCINOMA OF THE PROSTATE GLAND
}

\author{
By ALEXANDER B. GUTMAN aNd ETHEL BENEDICT GUTMAN \\ (From the Department of Medicine, College of Physicians and Surgeons, Columbia University \\ and the Presbyterian Hospital, New York City)
}

(Received for publication April 8, 1938)

In 1935, Kutscher and Wolbergs (1) found that normal prostate tissue is extraordinarily rich in a phosphatase with optimum activity at about $\mathrm{pH}$ 5.0. This observation was confirmed for normal and carcinomatous prostate tissue by Gutman, Sproul, and Gutman (2), who further noted the presence of "acid" phosphatase at the site of skeletal metastases secondary to carcinoma of the prostate gland.

The present investigation was directed toward the possibility that invasion of lymph or blood channels by prostate carcinoma might result in the escape into the circulating fluids of prostate phosphatase sufficient to cause a measurable increase in the "acid" phosphatase activity of blood serum. Significant amounts of such an "acid" phosphatase were found in the serum of 11 of 15 patients with disseminated carcinoma of the prostate gland. The "acid" phosphatase noted in the serum of these patients corresponds closely in its characteristics with prostate tissue phosphatase, as described by Kutscher and Wörner (3). Its properties differ in significant respects from those of recognized phosphatases of the blood.

With the exception of one case, no appreciable rise in "acid" serum phosphatase activity was noted in a variety of diseases other than carcinoma of the prostate gland, including conditions presenting marked increases in "alkaline" serum phosphatase activity. The determination proved to be helpful in the diagnosis of disseminated carcinoma of the prostate gland.

\section{METHODS}

The method of King and Armstrong (4) has been shown to be readily adaptable to the estimation of phosphatase activity on the acid side of neutrality (2). Preliminary experiments indicated that $\mathrm{pH} 4.9$ was within the optimum range of activity of the serum phosphatase with which we are here concerned, and beyond the range of significant activity of "alkaline" serum phosphatase. The buffer-substrate employed was M/200 disodium monophenylphosphate in Sørensen's $\mathrm{M} / 10$ citrate $-\mathrm{HCl}$ buffer adjusted to $\mathrm{pH} 4.8$. After addition of serum, the $\mathrm{pH}$ of the reaction mixture at room temperature was 4.85 (glass electrode measurements), and therefore approximately 4.9 at the temperature of hydrolysis, $37^{\circ} \mathrm{C}$. The time of hydrolysis was 3 to 5 hours, except in most cases of metastatic prostate carcinoma in which the optimum time of hydrolysis was $1 / 2$ to 1 hour. Apart from these deviations, the procedure followed was essentially that outlined by King and Armstrong (4). The results are expressed in units of phosphatase activity per $100 \mathrm{cc}$. of serum. A unit is defined as that degree of phosphatase activity which at $\mathrm{pH} 4.9$ and $37^{\circ} \mathrm{C}$. will liberate from the specified buffer-monophenylphosphate substrate solution $1 \mathrm{mgm}$. of phenol in 1 hour.

"Alkaline" phosphatase activity of the serum was determined by the method of Bodansky (5).

\section{RESULTS AND DISCUSSION}

"Acid" phosphatase activity of normal serum. Normal sera consistently show slight but measurable hydrolysis of monophenylphosphate substrate buffered with citrate- $\mathrm{HCl}$ to $\mathrm{pH} 4.9$ (6; $c f$. Roche (7)). The range of variation in normal subjects tentatively appears to be 0.5 to 2.5 units (6), as defined above.

That the hydrolysis is enzymatic is indicated by the absence of scission in control experiments in which substrate-buffer mixtures were maintained at $37^{\circ}$ for 5 hours without the addition of serum. A study of this reaction (6), suggests that the enzyme involved is not "alkaline" serum phosphatase. Normal serum apparently contains minute amounts of one or more phosphatases of the type classified by Folley and Kay $(8,9)$ as phosphomonoesterase $A_{2}$. The properties of this "acid" phosphatase do not coincide with those of erythro- 
TABLE I

"Acid" and "alkaline" phosphatase actioity of the serum in patients with disease of the prostate gland

\begin{tabular}{|c|c|c|c|c|c|}
\hline \multirow{2}{*}{$\begin{array}{c}\text { Case } \\
\text { number }\end{array}$} & \multirow[t]{2}{*}{ Age } & \multicolumn{2}{|c|}{$\begin{array}{l}\text { Serum phosphatase } \\
\text { activity * }\end{array}$} & \multirow[t]{2}{*}{ Basis for diagnosis } & \multirow[t]{2}{*}{ Remarks } \\
\hline & & $\mathrm{pH} 4.9$ & pH 8.6 & & \\
\hline & years & $\begin{array}{l}\text { units per } \\
100 \text { cc. }\end{array}$ & $\begin{array}{c}\text { Bodansky units } \\
\text { per } 100 \text { cc. }\end{array}$ & & \\
\hline
\end{tabular}

A. Metastasizing CaRcinoma of the prostate gland

\begin{tabular}{|c|c|c|c|c|c|}
\hline 1 & 60 & 516. & 7.2 & $\begin{array}{l}\text { Resection } \\
\text { (Recurrence) }\end{array}$ & $\begin{array}{l}\text { Rapid extension of osteolytic metastases to pelvis, ribs (fractures), } \\
\text { spine (collapse), scapulae, humeri (fracture), femora }\end{array}$ \\
\hline 2 & 63 & 40.8 & 12.9 & Clinical & $\begin{array}{l}\text { Predominantly osteolytic metastases to clavicle, pelvis. Spine } \\
\text { tender but } x \text {-rays negative }\end{array}$ \\
\hline 3 & 60 & 38.6 & 17.3 & $\begin{array}{c}\text { Resection } \\
\text { (Recurrence) }\end{array}$ & $\begin{array}{l}\text { Osteoplastic-osteolytic metastases to pelvis, spine, ribs (fracture), } \\
\text { femur, humerus }\end{array}$ \\
\hline 4 & 60 & 26.3 & 21.4 & Clinical & $\begin{array}{l}\text { Osteoplastic metastases to pelvis, spine, femora, clavicles, scapulae, } \\
\text { humeri, skull }\end{array}$ \\
\hline 5 & 75 & 10.7 & 4.2 & Resection & Early osteolytic-osteoplastic metastases to spine \\
\hline 6 & 60 & 10.6 & 27.7 & Clinical & Osteolytic - osteoplastic metastases to pelvis, femora, spine \\
\hline 7 & & 7.4 & 19.0 & Clinical & Osteoplastic -osteolytic metastases to spine \\
\hline 8 & 61 & 6.8 & 9.5 & Biopsy & Osteoplastic metastases to pelvis, spine \\
\hline 9 & 73 & 5.6 & 4.5 & $\begin{array}{c}\text { Resection } \\
\text { (?Recurrence) }\end{array}$ & Osteolytic - osteoplastic metastases to pelvis \\
\hline 10 & 56 & 5.4 & 50.0 & $\begin{array}{c}\text { Resection } \\
\text { (No recurrence) }\end{array}$ & $\begin{array}{l}\text { Rapid extension of discrete osteoplastic metastases to pelvis, femora, } \\
\text { spine, scapulae, humeri }\end{array}$ \\
\hline 11 & 61 & 4.4 & 21.6 & Autopsy & Osteoplastic-osteolytic metastases to pelvis, spine, skull \\
\hline 12 & 62 & 3.1 & 20.1 & $\begin{array}{c}\text { Resection } \\
\text { (No recurrence) }\end{array}$ & $\begin{array}{l}\text { Osteoplastic metastases to spine, pelvis, femora, humeri, scapulae, } \\
\text { skull }\end{array}$ \\
\hline 13 & 70 & 1.6 & 2.8 & Biopsy & Questionable metastases $L_{6}$ and sacrum \\
\hline 14 & 67 & 1.6 & 12.0 & Biopsy & $\begin{array}{l}\text { Osteolytic-osteoplastic metastases to pelvis. Rectovesical fistula } \\
\text { after radium. }\end{array}$ \\
\hline 15 & 56 & 1.5 & 3.9 & $\begin{array}{c}\text { Resection } \\
\text { (No recurrence) }\end{array}$ & No bone metastases by $x$-ray \\
\hline
\end{tabular}

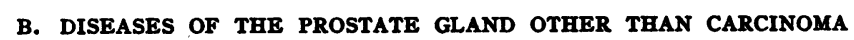

\begin{tabular}{c|c|c|c|c|c}
\hline 16 & 73 & 2.1 & 11.7 & Resection & $\begin{array}{l}\text { Sections show only benign hypertrophy of prostate. Osteoplastic- } \\
\text { osteolytic metastases to skull, spine, pelvis. Primary not known }\end{array}$ \\
\hline 17 & & 1.9 & 2.4 & Autopsy & $\begin{array}{l}\text { Sections show only benign hypertrophy of prostate. Osteolytic } \\
\text { metastases to scapula, lungs secondary to hypernephroma }\end{array}$ \\
\hline 18 & 44 & 1.6 & 2.9 & Resection & Lymphosarcoma of prostate gland \\
\hline 19 & 30 & 1.2 & 5.0 & Clinical & Acute prostatitis \\
\hline 20 & 67 & 1.1 & 3.2 & Clinical & Benign hypertrophy of prostate; uremia \\
\hline
\end{tabular}

* Normal range of serum phosphatase activity: pH $4.9=0.5$ to 2.5 units per 100 cc. pH $8.6=1.0$ to 4.0 Bodansky units per $100 \mathrm{cc}$. 
cyte phosphatase (7) but show a general correspondence with those of phosphatases found in liver, spleen, and kidney, as described in particular by Bamann and Riedel (10). That prostate tissue is not the source is indicated by the presence of this enzyme in the serum of normal female subjects and by the differences in properties to be described.

"Acid" phosphatase activity of the serum in patients with disseminated carcinoma of the prostate gland. As shown in Table IA, the phosphatase activity of the serum at $\mathrm{pH} 4.9$ was found to exceed maximal normal values in 12 of 15 cases of disseminated prostate carcinoma. In Case 1 the phosphatase activity was so great that it was necessary to dilute the serum 5 times in order to make valid comparisons with our standard solutions. The value thus obtained (516 units per $100 \mathrm{cc}$.) was repeatedly checked with phenylphosphate substrate. Roughly equivalent results were obtained with $\beta$ glycerophosphate substrate.

The data recorded in Table IA show a wide spread in the "acid" phosphatase activity of the serum in different patients with metastatic prostate carcinoma. Several factors doubtless contribute to this dispersion. It is known that the phosphatase content of normal prostate tissue, while consistently high, varies over a broad range (2). The " acid" phosphatase of prostate carcinoma at the site of metastases likewise exhibits marked differences in activity. In the lumbar vertebra of one case (2), we found 19.0 King and Armstrong units per gram of wet tissue, in two others (unpublished cases) 5.5 and 5.7 units. Certain therapeutic measures appear to affect the level of "acid" serum phosphatase activity in these patients. In Cases 12 and 15, complete resection of the primary prostate tumor had been performed without recurrence at the time of analysis. Case 14 had received extended treatment by implantation of radium seeds into the tumor mass, sufficient to cause the development of a rectovesical fistula. The rapidity of extension of the neoplasm may also influence the level of "acid" serum phosphatase activity. Our highest value was obtained in a patient (Case 1) in whom the development of skeletal metastases was so rapid as to excite repeated comment. In Case 13, whose values were within normal limits, the only indications of metastases were two equivocal areas of sclerosis in the fifth lumbar and the adjacent sacral vertebrae in a patient with scoliosis of long standing. No correlation could be made out, however, between the level of "acid" serum phosphatase activity and the extensiveness of osteoplastic skeletal metastases found in roentgenograms. In fact, the highest value observed was in a patient with predominantly osteolytic metastases (Case 1).

The data recorded in Table IA give no indication of any correlation between the level of "acid" phosphatase activity of the serum and that of "alkaline" serum phosphatase activity. As pointed out elsewhere $(11,12,13)$, the " alkaline" phosphatase activity of the serum is often markedly elevated in patients with widespread osteoplastic metastases secondary to prostate carcinoma, the degree of elevation being roughly proportional to the extent of osteoplastic skeletal metastases found in roentgenograms $(12,13,14)$.

TABLE II

Comparison of pH-activity curves of prostate tissue phosphatase with those of serum phosphatase in 2 cases of metastasizing carcinoma of the prostate gland

(M/200 monophenylphosphate substrate; $\mathrm{M} / 10$ citrate buffer; $t=37^{\circ} \mathrm{C}$.)

\begin{tabular}{|c|c|c|c|c|c|c|c|c|c|c|}
\hline $\mathrm{pH}$ (glass electrode measurements) ...... & 2.2 & 3.5 & 3.86 & 4.37 & 4.76 & 5.06 & 5.97 & 6.54 & 7.31 & 7.65 \\
\hline $\begin{array}{l}\text { Normal prostate tissue (mgm. phenol liberated in } 1 / 2 \text { hour, per } 100 \\
\text { cc. extract ( } 1 \text { gram of wet tissue: } 2,360 \text { cc. of water) ) ......... }\end{array}$ & 0 & 7.3 & 8.1 & 11.9 & 12.1 & 14.0 & 14.8 & 12.5 & 7.3 & 2.3 \\
\hline $\begin{array}{l}\text { Carcinomatous prostate tissue, Case } 11 \text { (mgm. phenol liberated in } 1 / 2 \\
\text { hour, per } 100 \mathrm{cc} \text {. extract ( } 1 \text { gram of wet tissue: } 648 \mathrm{cc} \text {. of water) ) }\end{array}$ & 0.3 & 12.4 & 14.7 & 16.5 & 18.9 & 21.7 & 22.5 & 21.1 & 10.5 & 5.5 \\
\hline $\begin{array}{l}\text { Serum of Case } 1 \text { (mgm. phenol liberated in } 1 / 2 \text { hour, per } 100 \mathrm{cc} . \text { of } \\
\text { serum diluted } 1: 20) \ldots \ldots \ldots \ldots \ldots \ldots \ldots \ldots \ldots \ldots \ldots \ldots \ldots \ldots \ldots \ldots \ldots\end{array}$ & 0.7 & 8.7 & 10.7 & 12.1 & 12.9 & 13.6 & 15.6 & 14.4 & 7.7 & 4.3 \\
\hline $\begin{array}{l}\text { Serum of Case } 2 \text { (mgm. phenol liberated in } 1 \text { hour, per } 100 \mathrm{cc} . \text { of serum } \\
\quad \text { diluted } 1: 2) \ldots \ldots \ldots \ldots \ldots \ldots \ldots \ldots \ldots \ldots \ldots \ldots \ldots \ldots \ldots \ldots \ldots \ldots \ldots\end{array}$ & & & 16.8 & 17.8 & 20.4 & 22.0 & 23.2 & 19.8 & 7.2 & 3.4 \\
\hline
\end{tabular}


No significant rise in " acid" serum phosphatase activity was found in diseases of the prostate gland other than carcinoma with metastases (Table IB).

Comparison of properties of prostate tissue phosphatase with those of "acid" phosphatase of the serum of patients with disseminated carcinoma of the prostate gland. The results summarized in Table II show satisfactory agreement between the $\mathrm{pH}$-activity curves of prostate tissue phosphatase and those of serum phosphatase in two cases of carcinoma of the prostate gland with metastases. The dilutions indicated in the table compensate for differences in concentration of the enzyme in prostate tissue and in serum. In order to approximate initial reaction velocities, the time of hydrolysis was made as short as was consistent with accurate readings. Comparison with the data of Kutscher and Wörner (3) shows a general correspondence in the broad range of optimum activity but with the concentration of substrate and conditions of hydrolysis selected, our peak of activity was found to be closer to neutrality.

In confirmation of Kutscher and Wörner (3), the activity of prostate tissue phosphatase was found to vary widely with different concentrations of $\beta$ glycerophosphate substrate (Table III). This effect was less pronounced when molarities of disodium monophenylphosphate substrate varying within the range investigated (Table III) were employed at the same $\mathrm{pH}$. Similar results were obtained with serum from a case of disseminated prostate carcinoma (Table III).

Prostate tissue phosphatase is unusual in that it is rapidly and irreversibly inactivated by alcohols (3). The "acid" phosphatase activity of the serum in patients with carcinoma of the prostate gland is likewise inhibited by alcohols. A 1:20 dilution of the serum of Case 1, with 24.9 units of phosphatase activity, yielded a value of 17.6 units after one hour's incubation with added $\mathrm{N}$ propyl alcohol in a concentration of $M / 1$ in the reaction mixture. The hydrolysis in both experiments was conducted at $37^{\circ} \mathrm{C}$. with $\mathrm{M} / 200$ monophenylphosphate substrate in $\mathrm{M} / 10$ citrate buffer at $\mathrm{pH} 5.06$.

A parallel experiment performed under the same conditions, except for the use of sodium fluoride in a concentration of $\mathrm{M} / 100$ in the reaction mixture, resulted in reducing the activity of this serum (Case 1) from 24.9 to 5.6 units. As regards the inhibiting effect of fluoride too, then, the "acid" serum phosphatase corresponds with prostate tissue phosphatase. The "alkaline" phosphatase of serum, on the other hand, is not significantly inhibited by fluoride (8). This fact was utilized to contrast the effect of fluoride on the phosphatase activity of the serum in a patient with disseminated prostate carcinoma who presented elevated levels of both " acid" and " alkaline" phosphatase activity (Case 3). At pH 9.0, a sample of this serum showed no decrease in activity when hydrolysis was carried out for one-

TABLE III

Effect of variations in substrate concentration on activity of prostate tissue phosphatase and on activity of serum phosphatase from a case of metastasizing prostate carcinoma

A. SUBSTRATE $=\beta$ GLYCEROPHOSPHATE

(Buffer $\mathrm{M} / 25$ citrate; time 1 hour; $\mathrm{pH} 4.37 ; t=37^{\circ} \mathrm{C}$.)

\begin{tabular}{|c|c|c|c|c|c|c|c|c|c|c|}
\hline Molar concentration of substrate. & 0.006 & 0.0125 & 0.017 & 0.025 & 0.034 & 0.05 & 0.10 & 0.15 & 0.20 & 0.30 \\
\hline $\begin{array}{l}\text { Normal prostate tissue }(m g m . \text { phenol liberated per } 100 \text { cc. extract } \\
(1 \text { gram of wet tissue }: 2360 \text { cc. of water })) \ldots \ldots \ldots \ldots \ldots \ldots\end{array}$ & 4.0 & 5.4 & & 11.5 & & 13.7 & 14.9 & 14.8 & 12.4 & 9.5 \\
\hline $\begin{array}{l}\text { lerum of Case } 1 \text { (mgm. phenol liberated per } 100 \mathrm{cc} . \mathrm{s} \\
\text { ilution) }) \ldots \ldots \ldots \ldots \ldots \ldots \ldots \ldots \ldots \ldots \ldots \ldots \ldots \ldots \ldots\end{array}$ & 3.5 & 5.3 & 8.6 & 10.3 & 11.3 & 12.5 & 13.7 & 13.5 & 11.6 & 8.0 \\
\hline
\end{tabular}

B. SUBSTRATE $=$ MONOPHENYLPHOSPHATE

(Buffer $\mathrm{M} / 10$ citrate; time 1 hour; $\mathrm{pH} 4.37 ; t=37^{\circ} \mathrm{C}$.)

\begin{tabular}{|c|c|c|c|c|c|}
\hline Molar concentration of substrate $\ldots \ldots \ldots \ldots \ldots \ldots \ldots \ldots \ldots \ldots$ & 0.0025 & 0.005 & 0.01 & 0.02 & 0.05 \\
\hline $\begin{array}{l}\text { Normal prostate tissue }(\text { mgm. phenol liberated per } 100 \mathrm{cc} \text {. of extract }(1 \mathrm{gram} \text { of } \\
\text { wet tissue : } 2360 \mathrm{cc} \text {. of water }) \text { ) } \ldots \ldots \ldots \ldots \ldots \ldots \ldots \ldots \ldots \ldots \ldots \ldots \ldots \ldots \ldots\end{array}$ & 19.8 & 20.9 & 23.7 & 23.5 & 26.9 \\
\hline Serum of Case 1 (mgm. phenol liberated per $100 \mathrm{cc.} \mathrm{of} \mathrm{serum} \mathrm{(1:20} \mathrm{dilution))}$ & 18.7 & 19.4 & 20.0 & 22.2 & 26.0 \\
\hline
\end{tabular}


half hour at $37^{\circ} \mathrm{C}$. with sodium fluoride of $\mathrm{M} / 20$ concentration in the reaction mixture. The same serum liberated $18.3 \mathrm{mgm}$. of phenol at $\mathrm{pH} 4.4$ but, at this $\mathrm{pH}$, the conditions of hydrolysis otherwise unchanged, sodium fluoride of $\mathrm{M} / 20$ concentration in the reaction mixture reduced the activity in one-half hour to $2.2 \mathrm{mgm}$. of phenol liberated per $100 \mathrm{cc}$. serum.

A sample of the serum of Case 3 was employed also for a similar experiment with magnesium salts, which are known to activate "alkaline" serum phosphatase but have no effect upon prostate tissue phosphatase (3). At $\mathrm{pH} 9.0$, under the conditions of hydrolysis outlined in the preceding paragraph, $50.2 \mathrm{mgm}$. phenol were liberated in the presence of magnesium chloride ( $M / 50$ concentration in the reaction mixture), as contrasted with $33.0 \mathrm{mgm}$. phenol without the addition of $\mathrm{Mg}$ ion. At $\mathrm{pH} 4.4$, conditions of hydrolysis otherwise unchanged, $18.3 \mathrm{mgm}$. of phenol were liberated both in the presence and in the absence of added M/50 magnesium chloride. In another instance (Case 9), hydrolysis of $\mathrm{M} / 200$ phenylphosphate for 2 hours at $\mathrm{pH} 5.97$ and $37^{\circ} \mathrm{C}$. with $\mathrm{M} / 20$ magnesium chloride added yielded a value of 15.7 units as compared with 15.8 units without $\mathrm{Mg}$ ion.

The absence of any activating effect of magnesium salts on the "acid" phosphatase activity of the serum in patients with metastasizing prostate carcinoma contrasts with the marked activation of the "acid" phosphatase found in normal erythrocytes (7). These two "acid" phosphatases differ also with respect to their capacity to hydrolyze $\alpha$ glycerophosphate. Unlike erythrocyte phosphatase, the " acid" phosphatase found in the serum of patients with disseminated prostate carcinoma hydrolyzes the $\alpha$ isomer less rapidly than $\beta$ glycerophosphate. A sample of the serum of Case 1 in $1: 5$ dilution liberated $172 \mathrm{mgm}$. of phosphorus per $100 \mathrm{cc}$. in one hour from a $\beta$ glycerophosphate substrate at $\mathrm{pH} 4.9$, but only 87 mgm. of phosphorus from an $\alpha$ glycerophosphate substrate of the same molarity and under the same conditions of hydrolysis. ${ }^{1}$ Kutscher and Wolbergs (1) report that prostate tissue phosphatase splits about 10 per cent less of $\alpha$ glycerophosphate than of the $\beta$ isomer.

1 We are indebted to Dr. Frank L. Pyman for the $\alpha$ glycerophosphate used in these experiments.
"Acid" phosphatase activity of the serum in diseases other than carcinoma of the prostate gland. Included in Table IV are representative

TABLE IV

"Acid" and "alkaline" phosphatase activity of the serum in miscellaneous diseases

\begin{tabular}{|c|c|c|c|c|c|}
\hline \multirow{2}{*}{$\begin{array}{r}\text { 音 } \\
\text { 夏 } \\
\text { 总 } \\
\end{array}$} & \multirow{2}{*}{ 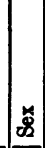 } & \multirow[b]{2}{*}{8} & \multicolumn{2}{|c|}{$\begin{array}{l}\text { Serum phospha- } \\
\text { tase activity }\end{array}$} & \multirow{2}{*}{ Diagnosis and remarks } \\
\hline & & & $\begin{array}{c}\mathrm{pH} \\
4.9\end{array}$ & pH 8.6 & \\
\hline 21 & $0^{*}$ & years & $\begin{array}{c}\text { units } \\
\text { per } \\
100 \\
\text { cc. } \\
3.4\end{array}$ & $\begin{array}{c}\text { Bodansky } \\
\text { units per } \\
100 \text { c. } \\
112.8\end{array}$ & Advanced Paget's disease \\
\hline 22 & ? & 63 & 5.0 & 79.1 & Advanced Paget's disease \\
\hline 23 & 9 & 65 & 1.6 & 38.0 & Advanced Paget's disease \\
\hline 24 & $0^{\pi}$ & 49 & 1.8 & 10.3 & Paget's disease of pelvis, spine \\
\hline 25 & 8 & 50 & 2.3 & 30.3 & Hyperparathyroidism \\
\hline 26 & $0^{\pi}$ & 1 & 1.9 & 18.0 & Rickets \\
\hline 27 & 8 & 26 & 1.0 & 5.3 & Osteomalacia \\
\hline 28 & 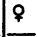 & 15 & 0.2 & 3.9 & Myositis ossificans \\
\hline 29 & $\sigma^{+}$ & 65 & 1.6 & 33.7 & $\begin{array}{c}\text { Carcinoma of head of pancreas, obstructive } \\
\text { jaundice }\end{array}$ \\
\hline 30 & $\sigma^{7}$ & 73 & 1.2 & 29.1 & $\begin{array}{l}\text { Carcinoma of head of pancreas, obstructive } \\
\text { jaundice }\end{array}$ \\
\hline 31 & $\sigma^{7}$ & 55 & 2.3 & 18.7 & Stone common duct, obstructive jaundice \\
\hline 32 & $0^{\pi}$ & 50 & 1.7 & 11.6 & Stone common duct, obstructive jaundice \\
\hline 33 & 9 & 65 & 1.0 & 68.6 & Biliary cirrhosis, jaundice \\
\hline 34 & $\sigma^{7}$ & 19 & 1.6 & 11.4 & Arsphenamine hepatitis, jaundice \\
\hline 35 & $0^{\pi}$ & 28 & 1.1 & 7.6 & Catarrhal jaundice \\
\hline 36 & $0^{7}$ & 53 & 1.4 & 2.3 & Hemolytic jaundice \\
\hline 37 & $a^{*}$ & & 1.2 & 9.2 & Chronic nephritis, nonprotein nitrogen 150 \\
\hline 38 & $0^{x}$ & 39 & 2.7 & 4.4 & Uremia, nonprotein nitrogen 125 \\
\hline 39 & $0^{x}$ & 57 & 1.2 & 4.4 & Multiple myeloma \\
\hline 40 & $0^{\pi}$ & 50 & 0.5 & 8.8 & Multiple myeloma \\
\hline 41 & $0^{\pi}$ & 69 & 1.0 & 3.4 & Lymphatic leukemia \\
\hline 42 & $0^{7}$ & 56 & 1.2 & 12.5 & Lymphosarcoma \\
\hline 43 & $\sigma^{7}$ & 60 & 2.5 & 6.4 & Osteogenic sarcoma? \\
\hline 44 & $0^{7}$ & 20 & 0.6 & 14.8 & Ewing's tumor, extensive bone involvement \\
\hline 45 & $\%$ & 44 & 1.8 & 9.8 & $\begin{array}{l}\text { Carcinoma of breast, extensive osteolytic meta- } \\
\text { stases }\end{array}$ \\
\hline 46 & 8 & & 1.2 & 12.4 & $\begin{array}{l}\text { Carcinoma (primary?), extensive osteolytic meta- } \\
\text { stases }\end{array}$ \\
\hline 47 & 9 & 72 & 1.6 & 23.8 & Carcinoma (primary?), extensive metastases \\
\hline 48 & 9 & 43 & 1.8 & 7.7 & Hypernephroma, extensive osteolytic metastases \\
\hline 49 & $\sigma^{7}$ & 70 & 1.8 & 33.3 & Carcinoma of sigmoid, liver metastases \\
\hline 50 & $\sigma^{7}$ & 71 & 0.6 & 4.9 & Carcinoma of stomach, metastases \\
\hline 51 & $\sigma^{7}$ & 60 & 1.6 & 9.7 & Seminoma, extensive metastases \\
\hline 52 & $\sigma^{7}$ & 65 & 0.6 & 2.3 & Carcinoma of rectum, resected, ? metastases \\
\hline 53 & $\sigma^{7}$ & 57 & 1.2 & 12.3 & Carcinoma (primary?), liver metastases \\
\hline 54 & $0^{*}$ & 74 & 1.1 & 9.1 & Carcinoma of gallbladder, liver metastases \\
\hline 55 & $\sigma^{\top}$ & 66 & 2.6 & 27.4 & Primary carcinoma of liver, jaundice \\
\hline
\end{tabular}


results obtained in the determination of "acid" serum phosphatase activity in diseases other than disseminated prostate carcinoma. In selecting cases for examination, special emphasis was placed upon conditions associated with elevated levels of "alkaline" serum phosphatase activity, including neoplasms of diverse origin. A variety of infections and miscellaneous conditions were also studied, the number of cases examined totalling 88.

The only value in excess of 4.0 units per $100 \mathrm{cc}$. encountered was in a female with widespread Paget's disease, who was found to have 5.0 units of " acid" serum phosphatase activity (and 79.1 Bodansky units per $100 \mathrm{cc}$. of " alkaline" phosphatase activity). Our series is too small, however, to warrant any statistical claim for specificity such as might be implied by this single exception.

As pointed out by Kay (15), the "alkaline" phosphatase activity of the serum may be increased in patients with neoplasm. The rise occurs chiefly in the presence of metastases to the skeleton and liver (16), the degree of elevation depending largely on the extent and character of these metastases $(12,13,14)$. The "acid" phosphatase activity of these patients, however, appears not to be affected appreciably, so far as we could determine, except when the primary tumor was in the prostate gland. In this respect (as in others), the enzyme reported here differs from that investigated by Schoonover and Ely (17) and others (8).

\section{SUMMARY}

Significantly increased " acid" phosphatase activity of the serum ( $>4.0$ units per $100 \mathrm{cc}$.) was found in 11 of 15 patients with metastasizing prostate carcinoma. The increase is due to the presence of a serum phosphatase which corresponds closely in its characteristics with prostate tissue phosphatase but differs in its properties from recognized phosphatases of the blood.

Sera of 88 patients with diseases other than disseminated prostate carcinoma did not, with one exception, yield values for " acid" phosphatase higher than 4.0 units per $100 \mathrm{cc}$. Included in this control series are many cases with marked elevations in "alkaline" serum phosphatase activity.

The determination of serum phosphatase ac- tivity at $\mathrm{pH} 4.9$ may be of limited value in the diagnosis of metastasizing carcinoma of the prostate gland.

\section{BIBLIOGRAPHY}

1. Kutscher, W., and Wolbergs, H., Prostataphosphatase. Ztschr. f. physiol. Chem., 1935, 236, 237.

2. Gutman, E. B., Sproul, E. E., and Gutman, A. B., Significance of increased phosphatase activity of bone at the site of osteoplastic metastases secondary to carcinoma of the prostate gland. Am. J. Cancer, 1936, 28, 485.

3. Kutscher, W., and Wörner, A., Prostataphosphatase. II. Ztschr. f. physiol. Chem., 1936, 239, 109.

4. King, E. J., and Armstrong, A. R., A convenient method for determining serum and bile phosphatase activity. Canad. M. A. J., 1934, 31, 376.

5. Bodansky, A., Phosphatase studies. II. Determination of serum phosphatase. Factors influencing the accuracy of the determination. J. Biol. Chem., 1933, 101, 93.

6. Gutman, A. B., and Gutman, E. B., "Acid" phosphatase activity of the serum of normal human subjects. Proc. Soc. Exper. Biol. and Med., 1938, 38, 470.

7. Roche, J., Blood-phosphatases. Biochem. J., 1931, 25, 1724.

8. Folley, S. J., and Kay, H. D., The phosphatases. Ergebn. d. Enzymforsch., 1936, 5, 159.

9. Folley, S. J., and Kay, H. D., The phosphatases. Tab. biol. period., 1937, 6, 268.

10. Bamann, E., and Riedel, E., Uber das Vorkommen zweier durch das $\mathrm{pH}-$ Wirkungsoptimum unterscheidbaren Phosphoesterasen in tierischen Organen. Ztschr. f. physiol. Chem., 1934, 229, 125.

11. Gutman, A. B., and Gutman, E. B., Paget's disease: Relative constancy of serum phosphatase levels over periods up to two years. Proc. Soc. Exper. Biol. and Med., 1935, 33, 150.

12. Gutman, A. B., Tyson, T. L., and Gutman, E. B., Serum calcium, inorganic phosphorus and phosphatase activity in hyperparathyroidism, Paget's disease, multiple myeloma and neoplastic disease of the bones. Arch. Int. Med., 1936, 57, 379.

13. Woodard, H. Q., Twombly, G. H., and Coley, B. L., A study of the serum phosphatase in bone disease. J. Clin. Invest., 1936, 15, 193.

14. Woodard, H. Q., and Higinbotham, N. L., The correlation between serum phosphatase and roentgenographic type in bone disease. Am. J. Cancer, 1937, 31, 220.

15. Kay, H. D., Plasma phosphatase. II. The enzyme in disease, particularly in bone disease. J. Biol. Chem., 1930, 89, 249.

16. Gutman, A. B., Swenson, P. C., and Parsons, W. B., The differential diagnosis of hyperparathyroidism. J. A. M. A., 1934, 103, 87.

17. Schoonover, J. W., and Ely, J. O., Enzymes in cancer. The $\beta$-glycerophosphatase of the erythrocytes. Biochem. T., 1935, 29, 115. 